\title{
Narrowband UVB Phototherapy for Clinically Isolated Syndrome: A Trial to Deliver the Benefits of Vitamin D and Other UVB-Induced Molecules
}

\author{
Prue H. Hart' ${ }^{1 *}$, Robyn M. Lucas ${ }^{1,2}$, David R. Booth ${ }^{3}$, William M. Carroll' ${ }^{4}$ David Nolan ${ }^{5,6}$, \\ Judith M. Cole ${ }^{7}$, Anderson P. Jones ${ }^{1}$ and Allan G. Kermode ${ }^{4,5}$

\begin{abstract}
${ }^{1}$ Telethon Kids Institute, University of Western Australia, Perth, WA, Australia, ${ }^{2}$ National Centre for Epidemiology and Public Health, Research School of Population Health, Australian National University, Canberra, ACT, Australia, ${ }^{3}$ The Westmead Institute for Medical Research, University of Sydney, Westmead, NSW, Australia, ${ }^{4}$ Centre for Neuromuscular and Neurological Disorders, Western Australian Neuroscience Research Institute, University of Western Australia, Sir Charles Gairdner Hospital, Perth, WA, Australia, ${ }^{5}$ Institute for Immunology and Infectious Disease, Murdoch University, Perth, WA, Australia, ${ }^{6}$ Royal Perth Hospital, Immunology Department, Perth, WA, Australia, ${ }^{7}$ St John of God Dermatology, Subiaco,
\end{abstract} \\ WA, Australia
}

\section{OPEN ACCESS}

Edited by: Björn Tackenberg,

University of Marburg, Germany

Reviewed by:

Anna Fogdell-Hahn,

Karolinska Institutet, Sweden

Klemens Ruprecht,

Charite - Universitätsmedizin Berlin,

Germany

*Correspondence: Prue H. Hart prue.hart@telethonkids.org.au

Specialty section: This article was submitted to

Multiple Sclerosis and

Neuroimmunology,

a section of the journal

Frontiers in Immunology

Received: 05 October 2016 Accepted: 03 January 2017 Published: 24 January 2017

Citation:

Hart PH, Lucas RM, Booth DR,

Carroll WM, Nolan D, Cole JM, Jones AP and Kermode AG (2017) Narrowband UVB Phototherapy for Clinically Isolated Syndrome: A Trial to Deliver the Benefits of Vitamin $D$ and Other UVB-Induced Molecules.

Front. Immunol. 8:3.

doi: 10.3389/fimmu.2017.00003
Low vitamin $\mathrm{D}$ and insufficient sun exposure are additive independent risk factors for the development of multiple sclerosis (MS). The usual measure of vitamin D status, serum 25-hydroxy vitamin $\mathrm{D}[25(\mathrm{OH}) \mathrm{D}]$, is also a marker of recent exposure to the UVB rays of sunshine. The main evidence for a protective effect for MS development of higher $25(\mathrm{OH})$ D comes from observational studies, but this study design cannot separate out whether $25(\mathrm{OH}) \mathrm{D}$ is acting as a marker of vitamin D status, sun exposure, or both. In light of a lack of definitive outcomes in MS patients after trials of vitamin D supplementation and the ability of narrowband UVB to induce vitamin D, as well as other immune-regulatory molecules in skin, the Phototherapy for Clinically Isolated Syndrome (PhoCIS) trial was established to investigate the benefits of narrowband UVB, in addition to supplemented vitamin D, on MS development in individuals with Clinically Isolated Syndrome. We propose that the PhoClS trial provides a fresh approach to re-defining the reported associations of $25(\mathrm{OH}) \mathrm{D}$ levels with MS development and progression.

Keywords: narrowband UVB phototherapy, vitamin D, multiple sclerosis, clinically isolated syndrome, UV-induced immunosuppression, trial, vitamin D supplementation

\section{INTRODUCTION}

Multiple sclerosis (MS) is a progressive currently incurable, immune-mediated disease of the central nervous system (CNS). Both genetic and environmental factors contribute to MS disease risk, largely through effects on immune pathways [reviewed in Ref. $(1,2)]$. Increasing MS incidence, prevalence and mortality with increasing latitude, seasonal effects in relapse rates, and association of MS risk in observational studies with less past sun exposure (1) have led to a focus on insufficient vitamin D as a major risk factor. This was further supported by season of birth effects for MS risk (3). However, studies in humans and mice by us and others [reviewed in Ref. $(4,5)$ ] suggest that immune regulation by UV radiation (UVR) is by both vitamin D-dependent and vitamin D-independent pathways. Our epidemiological work $(6,7)$ indicates that vitamin D and sun exposure are additive independent 
risk factors for MS development. A Swedish study has supported these findings (8). Further, direct effects of sun exposure on MRI measures of neurodegeneration in MS, independently of vitamin $\mathrm{D}$, have been reported (9). Thus, associations of 25(OH)D with MS disease progression cannot assume causality of vitamin $\mathrm{D}$ and the efficacy of supplementation in the MS disease process even if this is an effective way to raise $25(\mathrm{OH}) \mathrm{D}$ levels.

These findings suggest that multiple molecules, including vitamin $\mathrm{D}$, produced in the skin in response to UVR exposure, may contribute to the latitude gradient in incidence, prevalence, and mortality of MS. The question then becomes which strategy might we use to reduce the incidence of MS? Should it be vitamin D supplementation (surely the easiest option with proven safety), or is UVB exposure preferable as it will stimulate the production of vitamin $\mathrm{D}$ as well as the multiple other immune-modifying molecules (see below). Here, we introduce the Phototherapy for Clinically Isolated Syndrome (PhoCIS) Trial, which was designed to give individuals at high risk of MS the benefits of both vitamin $\mathrm{D}$ and other molecules produced in UVR-exposed skin. Recruitment of participants is ongoing, but here we provide the background and justification for the trial.

\section{THE PhOCIS TRIAL}

The PhoCIS trial examines the effects of narrow band UVB therapy on immune and inflammatory markers of disease, as well as MRI, in patients diagnosed with CIS within the last 120 days (ACTRN12614000185662). The protocol has received approval from the University of Western Australia Human Research Ethics Committee (2014-02-083), and informed consent has been obtained from each participant. All participants receive sufficient vitamin $\mathrm{D}$ supplementation to achieve serum $25(\mathrm{OH}) \mathrm{D}$ levels of $\geq 80 \mathrm{nmol} / \mathrm{L}$, as standard care. Half of the participants are randomized to receive the narrowband UVB phototherapy, in addition to vitamin $\mathrm{D}$ supplementation. The systemic immune-suppressing effect of UVR exposure has been extensively demonstrated in humans $(10,11)$. For example, a single sub-erythemal exposure of either 0.25 or 0.5 minimal erythemal dose (the dose of erythemally weighted UVR that causes a just perceptible reddening of the skin) of UVR suppressed contact hypersensitivity responses by 50 and $80 \%$, respectively, of volunteers with Fitzpatrick-defined human skin types I (always burns, never tans) and II (usually burns, tans with difficulty) $(12,13)$. Human and murine studies suggest a prominent role in UVR-induced immune suppression for dendritic cells (DCs) and induced T-regulatory and B-regulatory cells, culminating in reduced $\mathrm{T}$ and $\mathrm{B}$ cell responses [reviewed in $\operatorname{Ref} .(4,5,14)]$.

\section{Participants}

We plan to recruit 60 participants, of which 30 will receive narrowband UVB phototherapy. All participants in PhoCIS have been diagnosed with CIS, the first clinical presentation of a disease that shows characteristics of inflammatory demyelination that could be MS, but has yet to fulfill the criterion of progression in time, i.e., the participants have had only a single clinical episode (15). The primary end point is progression to MS, i.e., a second exacerbation defined by imaging (gadolinium-enhancing lesions or new or unequivocally enlarging T2 lesions) (16). CIS is recognized as a time when the disease course may be more susceptible to intervention resulting in deviation or slowing of disease development. Clinical trials of interferon beta-1a (17) or glatiramer acetate (18) have shown that individuals with CIS who receive treatment are less likely to develop a second exacerbation and have reduced MRI activity. In Australia, CIS patients are not eligible for disease-modifying therapy (DMT), which could complicate assessment of the modulating effects of narrow band UVB phototherapy.

\section{Intervention}

The intervention is very similar to that given to patients with psoriasis where narrow band UVB phototherapy has proven safe and effective, with very minimal adverse side effects $(19,20)$. Standard phototherapy (UVB between wavelengths 311-312 nm) is given three times/week for 8 weeks (24 exposures in total). Phototherapy is delivered according to the Dundee protocol; a starting dose of $20 \mathrm{~mJ} / \mathrm{cm}^{2}$ has been chosen based on knowledge of skin type and is well below the threshold for erythema for Fitzpatrick-defined skin types 1-II. All patients start with $40 \%$ increments on their initial dose, and this is reduced to $20 \%$ increments after six exposures. Using a similar protocol, narrow band UVB exposures were given three times/week for 4 weeks to 33 healthy adults with a mean $( \pm \mathrm{SD})$ baseline of $25(\mathrm{OH}) \mathrm{D}$ of $52.9 \pm 10.4 \mathrm{nmol} / \mathrm{L}(21)$. Serum 25(OH)D levels increased by a mean of $41.0 \mathrm{nmol} / \mathrm{L}$ (95\% CI 34.8-47.2) and support claims that narrow band UVB phototherapy will increase vitamin $\mathrm{D}$ status. For comparison, 25(OH)D levels increased by $20.2 \mathrm{nmol} / \mathrm{L}$ ( $95 \%$ CI 14.6-26.0) from a similar baseline in 30 individuals given $20 \mu \mathrm{g}$ (800 IU) oral cholecalciferol daily for 4 weeks (21).

\section{Assessment of Disease Progression}

Participants are followed for 12 months, both clinically and with repeated MRI (assessed after 3, 6, and 12 months) (Figure 1) and with assay of standard immunological biomarkers in

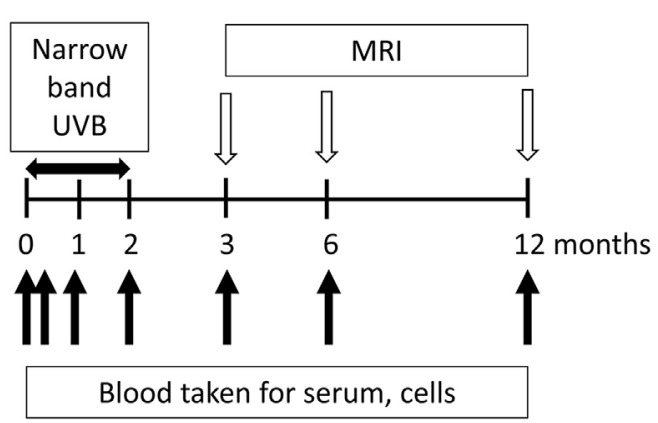

FIGURE 1 | Flow chart of the study design for Phototherapy for Clinically Isolated Syndrome. Participants are in the study for 12 months with half given narrowband UVB phototherapy. Blood is collected at the time of enrollment and after 7 days and 1, 2, 3, 6, and 12 months. Narrow band phototherapy is delivered three times per week for the first 8 weeks of their participation in the trial. Progression is monitored by MRIs after 3, 6, and 12 months. 
blood (beyond the scope of this paper). Blood is drawn by venepuncture at the time of enrollment and after the first week, first month, and second month (time of end of phototherapy for those receiving it). Blood is also drawn after 3, 6, and 12 months (Figure 1). We propose that due to the active exchange between blood and the CNS, assessments of the phenotype and function of blood cells will provide a window into changes at the site of the inflammatory, demyelinating lesions associated with development of MS.

The effects of narrowband UVB phototherapy have been previously investigated in nine patients with relapsing-remitting MS, i.e., a more established form of MS [mean time ( \pm SEM) since diagnosis, $13 \pm 8$ years] (22). All but two participants were on DMT (interferon $\beta$ 1a, natalizumab, glatiramer acetate). They were given sub-erythemal narrowband UVB phototherapy five times per week for 6 weeks and followed up by MRI and neurological testing for 6 months. Although there were no neurological improvements, the participants felt much better. Serum levels of 25(OH)D increased over the 6 weeks from $35.0 \pm 8.0$ to $103.7 \pm 10.6 \mathrm{nmol} / \mathrm{L}$ (mean $\pm \mathrm{SEM}, n=9)(22)$. Those treated showed an increase in T-regulatory cells and IL-10-producing DCs in UV-irradiated skin and an elevated subset of T-regulatory cells in the blood. When CD4+ cells from the blood were restimulated in vitro, they expressed less IL-21, which by its function may help to explain the increased T-regulatory cell numbers (23). The significance of these changes in individuals on DMT therapy is under investigation. In PhoCIS, the participants are DMT-free when recruited.

\section{WHY ESTABLISH PhOCIS WHILE A TRIAL OF ORAL VITAMIN D SUPPLEMENTATION WOULD BE EASIER?}

Supplementation of patients with CIS with oral vitamin D would be simpler and easier to manage. With respect to prevention of MS, there have been two previous studies. The first was a randomized controlled trial in Iran of 30 optic neuritis patients given 50,000 IU vitamin $\mathrm{D}_{3}$ per week for 12 months (24). There were significantly fewer cases of a second demyelinating attack measured on MRI in the treated group. The second study was a retrospective case-control study in Norway of self-reported consumption of cod liver oil ( $5 \mathrm{~mL}$ contains $400 \mathrm{IU}$ vitamin $\mathrm{D}$ ), during childhood, adolescence, and adulthood by MS adults diagnosed for $<10$ years (25). A significant reduction of risk for cod liver oil consumption was recorded only for intake during adolescence. Thus, there is some but limited evidence of a potential benefit of vitamin D supplementation for the prevention of MS and the two reported studies require verification. In Australia, the PrevANZ study is examining the effects of oral vitamin D supplementation on individuals with CIS with the end point of progression to MS by MRI criteria (ACTRN12612001160120). A similar trial has been established in France (D-Lay-MS, NCT01817166).

The majority of published studies have investigated the treatment of MS with vitamin D; these were recently detailed in a Rapid Response Report by the Canadian Agency for Drugs and Technologies in Health (26). The authors evaluated the clinical effectiveness of vitamin D supplementation in four systematic reviews (27-30), eight randomized controlled trials (24, 31-37), and three non-randomized studies $(25,38,39)$. The authors of the CADTH Rapid Report concluded that "the outcomes of vitamin D supplementation for MS were heterogeneous, conflicting and inconsistent, with no effect on disability scores and relapse rates. Further, there were both positive and negative results for immunologic factors, imaging studies, and functional outcomes." Other studies suggest that ongoing inflammation, as in MS, may hinder systemic increases in $25(\mathrm{OH}) \mathrm{D}$ levels with supplementation (40).

\section{PROPOSED MECHANISM OF PREVENTION OF MS DEVELOPMENT BY UVB PHOTOTHERAPY: VITAMIN D-DEPENDENT PATHWAYS}

The precursor of vitamin D in keratinocytes, 7-dehydrocholesterol, absorbs UVB photons to initiate a pathway of vitamin D production, followed by hydroxylations in the liver, kidney, and immune and epithelial cells, and ultimately the biosynthesis of 1,25-dihydroxy vitamin $\mathrm{D}\left[1,25(\mathrm{OH})_{2} \mathrm{D}\right]$, the active form of vitamin D (41). Unless supplemented, humans obtain up to $80 \%$ of their vitamin D by sun exposure. Many recent reviews have covered the immunomodulatory properties of $1,25(\mathrm{OH})_{2} \mathrm{D}(42)$, particularly with reference to regulation of cells proposed important to the development of MS. Genetic variation of the Vitamin D regulating genes, CYP27B1 and CYP24A1, have also been identified as risk factors (2). Many of the properties of $1,25(\mathrm{OH})_{2} \mathrm{D}$ have been detected in vitro with isolated cell populations and using concentrations of $1,25(\mathrm{OH})_{2} \mathrm{D}$ that are much higher than systemic levels, including pharmacological doses. However, immune cells have the enzymes to convert vitamin $\mathrm{D}$ or $25(\mathrm{OH}) \mathrm{D}$ to $1,25(\mathrm{OH})_{2} \mathrm{D}$, and local concentrations, at the level of the cells, may be much higher than systemic levels (43). Generally, there is evidence that $1,25(\mathrm{OH})_{2} \mathrm{D}$ can stimulate the generation of tolerogenic DCs (44), and enhance both the number and function of T-regulatory cells (45). Direct effects on all immune cell types have been reported, which is supported by their expression of the vitamin $\mathrm{D}$ receptor. There are also many effects of vitamin D on human immune cells that are still not fully understood, particularly as responses by human and murine cells can vary. For example, $25(\mathrm{OH})_{2} \mathrm{D}$ can control $\mathrm{T}$ cell antigen receptor signaling and activation of human but not murine T cells (46). Furthermore, trials of vitamin D supplementation for multiple conditions have generally been disappointing $(30,47,48)$ and have raised questions about the immunomodulatory abilities of vitamin $\mathrm{D}$ in vivo.

UV radiation-induced vitamin D may also regulate the development of MS by its effects on VDR-expressing non-immune cells in the CNS. In one study of CIS patients, each $25 \mathrm{nmol} / \mathrm{L}$ increase in $25(\mathrm{OH}) \mathrm{D}$ level was significantly associated with $7.8 \mathrm{~mL}$ higher gray matter volume, and there was a trend for an inverse relationship over 12 months between 25(OH)D levels and new brain lesions and clinical relapses (49). As vitamin D 
maternal deficiency has been associated with altered development of multiple organs before birth (50), it is possible that vitamin D may positively regulate re-myelination programs.

\section{PROPOSED MECHANISM OF PREVENTION OF MS DEVELOPMENT BY UVB PHOTOTHERAPY: VITAMIN D-INDEPENDENT PATHWAYS}

Several chromophores in skin for UVB photons have been implicated in vitamin D-independent pathways: trans-urocanic acid in the stratum corneum, DNA, RNA, lipids and tryptophan of keratinocytes, and antigen-presenting cells [reviewed in Ref. (4, $5,10,11)]$. All may initiate pathways involved in signaling from skin to immune cells in draining lymph nodes and tissues beyond. It has been shown that T-regulatory cells are induced locally but then migrate to sites of inflammation, including the CNS, for regulation of experimental autoimmune encephalomyelitis (EAE), the murine model of MS (22). Epidermal Langerhans cells have been implicated in the immune regulation of narrowband UVB phototherapy (51). Importantly, sub-erythemal amounts of UVR, as in narrowband UV phototherapy, can suppress both local and systemic immunity, measured functionally by reduced cellmediated immune responses. A recent advance in understanding the immune regulation by sub-erythemal UVR has come from studies of keratinocyte-derived host defense peptides, previously called antimicrobial peptides. These peptides have modest antimicrobial activity but rather pleiotropic immunoregulatory properties (52). They are produced in sub-erythemal UV-irradiated skin in the absence of any inflammation (53); they include cathelicidin LL-37 and the $\alpha$ - and $\beta$-defensins (52). As shown in a murine model, $\beta$-defensins via induction of T-regulatory cells can prevent and mitigate EAE (54). Recent studies have also implicated UVR in the maintenance of a pool of B-regulatory cells in the periphery that can prevent an autoimmune attack on the CNS (55). Narrow band UVB irradiation can also increase peripheral T-regulatory cell numbers and their suppressive function in patients with polymorphic light eruption (56).

Further advances to understanding the long-term effects of UVR exposure have come from studies of myeloid progenitors in the bone marrow of UV-irradiated mice (57-59). Immune cells in peripheral organs, including DCs that are the most important cells in initiating immunity, are constantly being replaced by bone marrow-derived hemopoietic cells. We have shown that a single irradiation of skin with erythemal UVR, or multiple sub-erythemal exposures, can suppress contact hypersensitivity responses at distant skin sites for between 1 and 3 months, and suggests bone marrow involvement per se $(58,60)$. Using chimeric mice engrafted with bone marrow from UV-irradiated mice, UV irradiation of skin alters the differentiation program of myeloid progenitors in bone marrow, so terminally differentiated DCs and macrophages are less immunogenic and more regulatory $(58,60)$. The reduced immunogenicity (confirmed in skin and airways) causes an attenuated ability of bone marrow-derived DCs to respond to inflammatory signals and associated antigens, and to prime new immune responses $(58,60)$. Adoptive transfer of DCs differentiated from the bone marrow of UV-irradiated mice and loaded in vitro with antigen can reduce inflammatory challenge responses in mice already sensitized to that antigen $(58,60)$, a scenario that can be likened to injected DCs suppressing ongoing autoimmune disease, such as MS. Importantly, the effect of suberythemal UVR to skin on bone marrow myeloid progenitors is by a vitamin $\mathrm{D}$-independent, prostaglandin $\mathrm{E}_{2}\left(\mathrm{PGE}_{2}\right)$-dependent process (57), with an epigenetic modification of an early myeloid progenitor in the bone marrow proposed. Involvement of UVR, bone marrow-differentiated DCs, and $\mathrm{PGE}_{2}$ in MS pathogenesis is supported by the identification of the gene encoding PTGER4, a $\mathrm{PGE}_{2}$ receptor that is an intermediary for the UV effects on DC progenitors in the bone marrow, as an MS risk factor in genome-wide association studies (2). We propose that in patients with CIS, exposure to narrow band UVB will similarly alter the immunogenic properties of circulating DCs and their precursor cells toward a regulatory profile. As UVB exposure can simulate innate immunity (61), we do not anticipate detrimental effects of the narrowband UVB phototherapy on host responses to infection.

\section{CONCLUSION}

Association of lower 25(OH)D levels with increased risk of MS and greater relapse rate, and the plausibility of $1,25(\mathrm{OH})_{2} \mathrm{D}$ as a biochemical modulator of MS pathogenic processes, has encouraged multiple trials of vitamin D supplementation. However, the inconclusive outcomes to date of these trials encourage a fresh approach to re-interpret the reported associations. As 25(OH)D levels are generally a measure of recent sun exposure, we propose that the source of $25(\mathrm{OH}) \mathrm{D}$ on MS prevention is investigated. The PhoCIS trial has been established for individuals with CIS who are administered narrowband UVB phototherapy 24 times over 8 weeks and assessed neurologically and immunologically for 12 months. There are multiple immunomodulatory agents, in addition to vitamin D, produced in UVB-irradiated skin; we propose that by giving individuals at high risk of developing MS narrowband UVB phototherapy that they will gain the benefits of both vitamin $\mathrm{D}$ and other molecules implicated in UVB-induced immunoregulation.

\section{AUTHOR CONTRIBUTIONS}

$\mathrm{PH}, \mathrm{AK}, \mathrm{RL}, \mathrm{DB}, \mathrm{WC}$, and $\mathrm{DN}$ conceived the idea to perform the trial and contributed to trial design. JC is the dermatologist in the team; $\mathrm{AJ}$ is the trial co-ordinator. All the authors contributed to drafting the manuscript and have approved the final version of the manuscript.

\section{FUNDING}

This study was supported by the National Health and Medical Research Council of Australia (ID 1067209). 


\section{REFERENCES}

1. Ascherio A, Munger KL, Lunemann JD. The initiation and prevention of multiple sclerosis. Nat Rev Neurol (2012) 8:602-12. doi:10.1038/nrneurol.2012.198

2. International Multiple Sclerosis Genetics Consortium (IMSGC), Beecham AH, Patsopoulos NA, Xifara DK, Davis MF, Kemppinen A, et al. Analysis of immune-related loci identifies 48 new susceptibility variants for multiple sclerosis. Nat Genet (2013) 45:1353-60. doi:10.1038/ng.2770

3. Dobson R, Giovannoni G, Ramagopalan S. The month of birth effect in multiple sclerosis: systematic review, meta-analysis and effect of latitude. J Neurol Neurosurg Psychiatry (2013) 84:427-32. doi:10.1136/jnnp-2012-303934

4. Hart PH, Gorman S, Finlay-Jones JJ. Modulation of the immune system by UV radiation: more than just the effects of vitamin D? Nat Rev Immunol (2011) 11:584-96. doi:10.1038/nri3045

5. Ullrich SE, Byrne SN. The immunologic revolution: photoimmunology. J Invest Dermatol (2012) 132:896-905. doi:10.1038/jid.2011.405

6. Taylor BV, Lucas RM, Dear K, Kilpatrick TJ, Pender MP, van der Mei IA, et al. Latitudinal variation in incidence and type of first central nervous system demyelinating events. Mult Scler (2010) 16:398-405. doi:10.1177/ 1352458509359724

7. Lucas RM, Ponsonby AL, Dear K, Valery PC, Pender MP, Taylor BV, et al. Sun exposure and vitamin D are independent risk factors for CNS demyelination. Neurology (2011) 76:540-8. doi:10.1212/WNL.0b013e31820af93d

8. Baarnhielm M, Hedstrom AK, Kockum I, Sundqvist E, Gustafsson SA, Hillert $\mathrm{J}$, et al. Sunlight is associated with decreased multiple sclerosis risk: no interaction with human leukocyte antigen-DRB1*15. Eur J Neurol (2012) 19:955-62. doi:10.1111/j.1468-1331.2011.03650.x

9. Zivadinov R, Treu CN, Weinstock-Guttman B, Turner C, Bergsland N, O'Connor $\mathrm{K}$, et al. Interdependence and contributions of sun exposure and vitamin D to MRI measures in multiple sclerosis. J Neurol Neurosurg Psychiatry (2013) 84:1075-81. doi:10.1136/jnnp-2012-304661

10. Norval M, McLoone P, Lesiak A, Narbutt J. The effect of chronic ultraviolet radiation on the human immune system. Photochem Photobiol (2008) 84:19-28. doi:10.1111/j.1751-1097.2007.00239.x

11. Norval M, Halliday GM. The consequences of UV-induced immunosuppression for human health. Photochem Photobiol (2011) 87:965-77. doi:10.1111/j.1751-1097.2011.00969.x

12. Kelly DA, Young AR, McGregor JM, Seed PT, Potten CS, Walker SL. Sensitivity to sunburn is associated with susceptibility to UVR-induced suppression of cutaneous cell-mediated immunity. J Exp Med (2000) 191:561-6. doi:10.1084/ jem.191.3.561

13. Fitzpatrick TB. The validity and practicality of sun reactive skin types I through VI. Arch Dermatol (1988) 124:869-71. doi:10.1001/archderm. 1988.01670060015008

14. Schwarz T. 25 Years of UV-induced immunosuppression mediated by T cellsfrom disregarded $\mathrm{T}$ suppressor cells to highly respected regulatory $\mathrm{T}$ cells. Photochem Photobiol (2008) 84:10-8. doi:10.1111/j.1751-1097.2007.00223.x

15. Lublin FD, Reingold SC, Cohen JA, Cutter GR, Sørensen PS, Thompson AJ, et al. Defining the clinical course of multiple sclerosis. Neurology (2014) 83:278-86. doi:10.1212/WNL.0000000000000560

16. Polman CH, Reingold SC, Banwell B, Clanet M, Cohen JA, Filippi M, et al. Diagnostic criteria for multiple sclerosis: 2010 revisions to the McDonald criteria. Ann Neurol (2011) 69:292-302. doi:10.1002/ana.22366

17. Jacobs LD, Beck RW, Simon JH, Kinkel RP, Brownscheidle CM, Murray TJ, et al. Intramuscular interferon beta 1a therapy initiated during a first demyelinating event in multiple sclerosis: CHAMPS Study Group. N Engl J Med (2000) 343:898-904. doi:10.1056/NEJM200009283431301

18. Comi G, Martinelli V, Rodegher M, Moiola L, Bajenaru O, Carra A, et al. Effect of glatiramer acetate on conversion to clinically definite multiple sclerosis in patients with clinically isolated syndrome (Pre-CISe study): a randomised, double-blind, placebo-controlled trial. Lancet (2009) 374:1503-11. doi:10.1016/S0140-6736(09)61259-9

19. Archier E, Devaux S, Castela E, Gallini A, Aubin F, Le Maître M, et al. Efficacy of psoralen UV-A therapy vs. narrowband UV-B therapy in chronic plaque psoriasis: a systematic literature review. J Eur Acad Dermatol Venereol (2012) 26(Suppl 3):11-21. doi:10.1111/j.1468-3083.2012.04519.x

20. Paul C, Gallini A, Archier E, Castela E, Devaux S, Aractingi S, et al. Evidence-based recommendations on topical treatment and phototherapy of psoriasis: systematic review and expert opinion of a panel of dermatologists. J Eur Acad Dermatol Venereol (2012) 26(Suppl 3):1-10. doi:10.1111/j.1468-3083.2012.04518.x

21. Ala-Houhala MJ, Vahavihu K, Hasan T, Kautiainen H, Ylianttila L, Viljakainen $\mathrm{HT}$, et al. Comparison of narrowband ultraviolet $\mathrm{B}$ exposure and oral vitamin D substitution on serum 25-hydroxyvitamin D concentration. Br J Dermatol (2012) 167:160-4. doi:10.1111/j.1365-2133.2012.10990.x

22. Breuer J, Schwab N, Schneider-Hohendorf T, Marziniak M, Mohan H, Bhatia $\mathrm{U}$, et al. Ultraviolet $\mathrm{B}$ light attenuates the systemic immune response in central nervous system autoimmunity. Ann Neurol (2014) 75:739-58. doi:10.1002/ ana. 24165

23. Korn T, Bettelli E, Oukka M, Kuchroo VK. IL-17 and Th17 cells. Annu Rev Immunol (2009) 27:485-517. doi:10.1146/annurev.immunol.021908.132710

24. Derakhshandi H, Etemadifar M, Feizi A, Abtahi SH, Minagar A, Abtahi MA, et al. Preventative effect of vitamin D3 supplementation on conversion of optic neuritis to clinically definite multiple sclerosis: a double blind, randomized, placebo-controlled pilot clinical trial. Acta Neurol Belg (2013) 113:257-63. doi:10.1007/s13760-012-0166-2

25. Cortese M, Riise T, Bjornevik K, Holmøy T, Kampman MT, Magalhaes S, et al. Timing of use of cod liver oil, a vitamin D source, and multiple sclerosis risk: The EnvlMS study. Mult Scler (2015) 21:1856-64. doi:10.1177/ 1352458515578770

26. CADTH Rapid Response Reports. Vitamin D for the treatment or prevention of multiple sclerosis: a review of the clinical effectiveness. Ottawa, ON: Canadian Agency for Drugs and Technologies in Health (2016).

27. Ganesh A, Apel S, Metz L, Paten S. The case for vitamin D supplementation in multiple sclerosis. Mult Scler Relat Disord (2013) 2:281-306. doi:10.1016/ j.msard.2012.12.008

28. James E, Dobson R, Kuhle J, Baker D, Giovannoni G, Ramagopalan SV. The effect of vitamin D-related interventions on multiple sclerosis relapses: a meta-analysis. Mult Scler (2013) 19:1571-9. doi:10.1177/1352458513489756

29. Pozuelo-Moyano B, Benito-Leon J, Mitchell AJ, Hernandez-Gallego J. A systematic review of randomized, double-blind, placebo-controlled trials examining the clinical efficacy of vitamin D in multiple sclerosis. Neuroepidemiology (2013) 40:147-53. doi:10.1159/000345122

30. Autier P, Boniol M, Pizot C, Mullie P. Vitamin D status and ill health: a systematic review. Lancet Diabetes Endocrinol (2014) 2:76-89. doi:10.1016/ S2213-8587(14)70049-X

31. Golan D, Halhal B, Glass-Marmor L, Staun-Ram E, Rozenberg O, Lavi I, et al. Vitamin D supplementation for patients with multiple sclerosis treated with interferon beta: a randomized controlled trial assessing the effect of flu-like symptoms and immunomodulatory properties. BMC Neurol (2013) 13:60. doi:10.1186/1471-2377-13-60

32. Aivo J, Hanninen A, Ilonen J, Soilu-Hanninen M. Vitamin D3 administration to MS patients leads to increased serum levels of latency activated peptide (LAP) of TGF-beta. J Neuroimmunol (2015) 280:12-5. doi:10.1016/ j.jneuroim.2015.01.005

33. Ashtari F, Toghianifar N, Zarkesh-Esfahani SH, Mansourian M. Short-term effect of high-dose vitamin D on the level of interleukin 10 in patients with multiple sclerosis: a randomized, double-blind, placebo-controlled clinical trial. Neuroimmunomodulation (2015) 22:400-4. doi:10.1159/000439278

34. Etemadifar M, Janghorbani M. Efficacy of high-dose vitamin D3 supplementation in vitamin D deficient pregnant women with multiple sclerosis: preliminary findings of a randomized control trial. Iran J Neurol (2015) 14:67-73.

35. Rosjo E, Steffensen LH, Jorgensen L, Lindstrøm JC, Šaltytè Benth J, Michelsen $\mathrm{AE}$, et al. Vitamin D supplementation and systemic inflammation in relapsingremitting multiple sclerosis. J Neurol (2015) 262:2713-21. doi:10.1007/ s00415-015-7902-5

36. Toghianifar N, Ashtari F, Zarkesh-Esfahani SH, Mansourian M. Effect of high dose vitamin D intake on interleukin-17 levels in multiple sclerosis: a randomized, double-blind, placebo-controlled clinical trial. J Neuroimmunol (2015) 285:125-8. doi:10.1016/j.jneuroim.2015.05.022

37. Sotirchos ES, Bhargava P, Eckstein C, Van Haren K, Baynes M, Ntranos A, et al. Safety and immunologic effects of high- versus low-dose cholecalciferol in multiple sclerosis. Neurology (2016) 86:382-90. doi:10.1212/ WNL.0000000000002316

38. Jelinek GA, Marck CH, Weiland TJ, Pereira N, van der Meer DM, Hadgkiss EJ. Latitude, sun exposure and vitamin D supplementation: associations 
with quality of life and disease outcomes in a large international cohort of people with multiple sclerosis. BMC Neurol (2015) 15:132. doi:10.1186/ s12883-015-0394-1

39. Najafipoor A, Roghanian R, Zarkesh-Esfahani SH, Bouzari M, Etemadifar M. The beneficial effects of vitamin D3 on reducing antibody titers against Epstein-Barr virus in multiple sclerosis patients. Cell Immunol (2015) 294:9-12. doi:10.1016/j.cellimm.2015.01.009

40. Bhargava P, Steele SU, Waubant E, Revirajan NR, Marcus J, Dembele M, et al. Multiple sclerosis patients have a diminished serologic response to vitamin D supplementation compared to healthy controls. Mult Scler (2016) 22:753-60. doi:10.1177/1352458515600248

41. Bouillon R, Carmeliet G, Verlinden L, van Etten E, Verstuyf A, Luderer HF, et al. Vitamin $D$ and human health: lessons from vitamin $D$ receptor null mice. Endocr Rev (2008) 29:726-76. doi:10.1210/er.2008-0004

42. Lucas RM, Byrne SN, Correale J, Ilschner S, Hart PH. Ultraviolet radiation, vitamin D and multiple sclerosis. Neurodegener Dis Manag (2015) 5:413-24. doi:10.2217/nmt.15.33

43. Lucas RM, Gorman S, Geldenhuys S, Hart PH. Vitamin D and immunity. F1000Prime Rep (2014) 6:118. doi:10.12703/P6-118

44. Ferreira GB, Vanherwegen A-S, Eelen G, Gutierrez ACF, Van Lommel L, Marchal K, et al. Vitamin D3 induces tolerance in human dendritic cells by activation of intracellular metabolic pathways. Cell Rep (2015) 10:711-25. doi:10.1016/j.celrep.2015.01.013

45. Chambers ES, Hawrylowicz CM. The impact of vitamin D on regulatory T cells. Curr Allergy Asthma Rep (2011) 11:29-36. doi:10.1007/s11882-010-0161-8

46. von Essen MR, Kongsbak M, Schjerling P, Olgaard K, Odum N, Geisler C. Vitamin D controls T cell antigen receptor signalling and activation of human T cells. Nat Immunol (2010) 11:344-9. doi:10.1038/ni.1851

47. Bolland MJ, Grey A, Gamble GD, Reid IR. The effect of vitamin D supplementation on skeletal, vascular, or cancer outcomes: a trial sequential meta-analysis. Lancet Diabetes Endocrinol (2014) 2:307-20. doi:10.1016/ S2213-8587(13)70212-2

48. Theodoratou E, Tzoulaki I, Zgaga L, Ioannidis JP. Vitamin D and multiple health outcomes: umbrella review of systematic reviews and meta-analyses of observational studies and randomised trials. BMJ (2014) 348:g2035. doi:10.1136/bmj.g2035

49. Mowry EM, Pelletier D, Gao Z, Howell MD, Zamvil SS, Waubant E. Vitamin $\mathrm{D}$ in clinically isolated syndrome: evidence for possible neuroprotection. Eur J Neurol (2016) 23:327-32. doi:10.1111/ene.12844

50. Hart PH, Lucas RM, Walsh JP, Zosky GR, Whitehouse AJ, Zhu K, et al. Vitamin $\mathrm{D}$ in fetal development: findings from a birth cohort study. Pediatrics (2015) 135:e167-73. doi:10.1542/peds.2014-1860

51. Taguchi K, Fukunaga A, Ogura K, Nishigori C. The role of epidermal Langerhans cells in NB-UVB-induced immunosuppression. Kobe J Med Sci (2013) 59:E1-9.

52. Hancock REW, Haney EF, Gill EE. The immunology of host defence peptides: beyond antimicrobial activity. Nat Rev Immunol (2016) 16:321-34. doi:10.1038/nri.2016.29
53. Cela EM, Friedrich A, Paz ML, Vanzulli SI, Keoni J, Gonzalez Maglio DH. Time-course study of different innate immune mediators produced by UV-irradiated skin: comparative effects of short and daily versus a single harmful UV exposure. Immunology (2014) 145:82-93. doi:10.1111/imm. 12427

54. Bruhs A, Schwarz T, Schwarz A. Prevention and mitigation of experimental autoimmune encephalomyelitis by murine b-defensins via induction of regulatory T cells. J Invest Dermatol (2016) 136:173-81. doi:10.1038/JID. 2015.405

55. Kok LF, Marsh-Wakefield F, Marshall JE, Gillis C, Halliday GM, Byrne SN. $\mathrm{B}$ cells are required for sunlight protection of mice from a CNS-targeted autoimmune attack. JAutoimmun (2016) 73:10-23. doi:10.1016/j.jaut. 2016.05.016

56. SchweintzgerN, Gruber-Wackernagel A, Reginato E, Bambath I, Quehenberger $\mathrm{F}$, Byrne SN, et al. Levels and function of regulatory $\mathrm{T}$ cells in patients with polymorphic light eruption: relation to photohardening. Br J Dermatol (2015) 173:519-26. doi:10.1111/bjd.13930

57. Ng RL, Bisley JL, Gorman S, Norval M, Hart PH. UV-irradiation of mice reduces the competency of bone marrow-derived $\mathrm{CD} 11 \mathrm{c}+$ cells via an indomethacin-inhibitable pathway. J Immunol (2010) 185:7207-15. doi:10.4049/ jimmunol.1001693

58. Ng RL, Scott NM, Bisley JL, Lambert MJ, Gorman S, Norval M, et al. Characterisation of regulatory dendritic cells differentiated from the bone marrow of UV-irradiated mice. Immunology (2013) 140:399-412. doi:10.1111/ imm. 12145

59. Ng RL, Scott NM, Strickland DH, Gorman S, Grimbaldeston MA, Norval M, et al. Altered immunity and dendritic cell activity in the periphery of mice after long-term engraftment with bone marrow from UV-irradiated mice. J Immunol (2013) 190:5471-84. doi:10.4049/jimmunol.1202786

60. Scott NM, Ng RL, Gorman S, Norval M, Waithman J, Hart PH. Prostaglandin $\mathrm{E}_{2}$ imprints a long-lasting effect on dendritic cell progenitors in the bone marrow. JLeukoc Biol (2014) 95:225-32. doi:10.1189/jlb. 0513294

61. Felton S, Navid AF, Schwarz A, Schwarz T, Glaser R, Rhodes LE. Ultraviolet radiation-induced upregulation of antimicrobial proteins in health and disease. Photochem Photobiol Sci (2013) 12:29-36. doi:10.1039/ c2pp25158b

Conflict of Interest Statement: The authors declare no competing interests that are of direct relevance to the current research.

Copyright $\odot 2017$ Hart, Lucas, Booth, Carroll, Nolan, Cole, Jones and Kermode. This is an open-access article distributed under the terms of the Creative Commons Attribution License (CC BY). The use, distribution or reproduction in other forums is permitted, provided the original author(s) or licensor are credited and that the original publication in this journal is cited, in accordance with accepted academic practice. No use, distribution or reproduction is permitted which does not comply with these terms. 